\title{
Characterization of cues from natural multi-species biofilms that induce larval attachment of the polychaete Hydroides elegans
}

\author{
Oi Shing Hung ${ }^{1}$, On On Lee ${ }^{1}$, Vengatesen Thiyagarajan ${ }^{2}$, Hong-Ping $\mathrm{He}^{1}$, Ying $\mathrm{Xu}^{1}$, \\ Hong Chun Chung ${ }^{1}$, Jian-Wen Qiu ${ }^{3}$, Pei-Yuan Qian ${ }^{1, *}$ \\ ${ }^{1}$ Department of Biology/Coastal Marine Laboratory, Hong Kong University of Science and Technology, Clear Water Bay, \\ Kowloon, Hong Kong SAR, China \\ ${ }^{2}$ School of Biological Sciences, University of Hong Kong, Pokfulam Road, Hong Kong, Hong Kong SAR, China \\ ${ }^{3}$ Department of Biology, Hong Kong Baptist University, Kowloon Tong, Kowloon, Hong Kong SAR, China
}

\begin{abstract}
Multi-species natural microbial biofilms have been identified as sources of cues to induce larval attachment of a broad range of sessile marine invertebrates. However, the chemical identities of the cues originating from these films have not been fully characterized. In this study, we isolated and characterized 2 compounds from natural biofilms that induced the larval attachment of the polychaete Hydroides elegans. Biofilms were developed on Petri dishes in seawater in the field for $6 \mathrm{~d}$, collected from the Petri dishes using cotton buds, and extracted using a combination of polar and non-polar solvents. The non-polar fraction was inductive to larval attachment and was thus further fractionated using HPLC. Bioassay-guided fractionation was used to locate the active compounds that were then structurally characterized by using nuclear magnetic resonance (NMR) spectroscopy. Two inductive compounds were identified, a hydrocarbon (6,9-heptadecadiene) and a fatty acid (12-octadecenoic acid), which are the first chemical cues inductive to larval attachment of marine invertebrates isolated from natural biofilms.
\end{abstract}

KEY WORDS: Inductive cues · Natural biofilms $\cdot$ Hydroides elegans $\cdot$ Fatty acid $\cdot$ Hydrocarbon

\section{INTRODUCTION}

Most benthic marine invertebrates have a complex life cycle including a planktonic larval phase. The larvae usually preferentially migrate to suitable habitats to begin their benthic adult phase (Thorson 1950). Recruitment success is dependent on the attachment of larvae to the favorable habitat (reviewed by Pawlik 1992). The location of attachment is influenced by various physical cues, such as surface roughness (Barnes 1956), color (Saucedo et al. 2005), and surface wettability (Dahlström et al. 2004), and biological cues such as the presence of conspecific adults (Jeffery 2002), prey (Hadfield \& Scheuer 1985), host organisms (Williamson et al. 2000), and biofilms (Qian et al. 2003, Hung et al. 2007).
Biofilms are agglomerates of macromolecules, bacteria, diatoms, protozoa, and fungi, enmeshed in a matrix of extracellular polymeric substances (Decho 2000). They occur on virtually all exposed substrata in the marine environment. It is, thus, reasonable to expect that larvae actively select sites with certain biofilm characteristics for attachment. Among different biofilm components, bacteria are sensitive to changes in environmental conditions and, thus, the bacterial community composition in biofilms can reflect local environmental conditions (Wieczorek et al. 1996 and references therein). The bacterial community composition of a biofilm is an important mediator of larval attachment (i.e. inducing or inhibiting attachment) for many benthic marine invertebrates, such as barnacles (Qian et al. 2003, Hung et al. 2007), corals (Webster et al. 
2004), and polychaetes (Lau et al. 2005). To date, the chemical composition of just 2 attachment cues from laboratory-developed bacterial biofilms has been partially characterized. These 2 cues were found to be carbohydrates that could induce attachment of the larvae of the polychaete Janua (Dexiospira) brasiliensis (Kirchman et al. 1981) and the larvae of the tunicate Ciona intestinalis (Szewzyk et al. 1991). The full spectrum of chemical cues from natural biofilms that are responsible for modulating larval attachment has not yet been fully characterized.

There are several fully characterized chemical compounds from different sources other than natural biofilms that induce larval attachment of benthic marine invertebrates. For example, histamine isolated from the host algae of the sea urchin Holopneustes purpurescens could induced the larval settlement of the sea urchin (Swanson et al. 2004). A pheromone isolated from conspecific adults and known as the settlement-inducing protein complex (SIPC) was found to be inductive for the settlement of Balanus amphitrite (Matsumura et al. 1998). Narains and anthosamines are putative attachment cues for ascidian larvae isolated from sponges (Tsukamoto et al. 1995). Jacarone isolated from the red alga Delesseria sanguinea induced attachment of the scallop Pecten maximus (Yvin et al. 1985). However, in previous studies, the ecological relevance of the identified compounds was not discussed. Our understanding of the role that biofilms play in larval attachment would be substantially enhanced if the chemical cues originating from natural biofilms were characterized.

The polychaete Hydroides elegans (Haswell) is a calcareous tube-building polychaete common in tropical and subtropical waters around the world. Like the life cycles of many sessile marine invertebrates, that of $H$. elegans includes a planktonic larval phase followed by benthic juvenile and adult phases. Biofilms have been shown to be key natural inducers for attachment of H. elegans larvae (e.g. Lau et al. 2005). H. elegans is therefore particularly suitable for examining the interactions between biofilms and larval attachment.

Our objective in the present study was to characterize the chemical cues from natural biofilms that could induce larval attachment of Hydroides elegans. We used bioassay-guided fractionation to isolate pure bioactive compounds from natural biofilms and characterized them using nuclear magnetic resonance (NMR) spectroscopy.

\section{MATERIALS AND METHODS}

Development of natural biofilms. Natural biofilms were allowed to develop on polystyrene Petri dishes.
Dishes without lids were placed into nylon mesh bags (mesh pore size $110 \mu \mathrm{m}$ ) to prevent the attachment of invertebrate larvae. The bags were submerged for $6 \mathrm{~d}$ at low-intertidal height $(\sim 1 \mathrm{~m}$ below the mean low water level) at the old airport (OA) site in Hong Kong $\left(22^{\circ} 19^{\prime} \mathrm{N}, 114^{\circ} 16^{\prime} \mathrm{E}\right)$. The OA site was chosen as a high recruitment rate of benthic invertebrates including the barnacle Balanus amphitrite and the polychaete Hydroides elegans had been found at this site. The dishes were then retrieved and transported in seawater to the laboratory. Prior to the bioassays, the dishes were dip-rinsed 10 times in $0.22 \mu \mathrm{m}$ filtered seawater (FSW) to remove any loosely attached biofilm.

Isolation and purification of bioactive compounds from natural biofilms. Natural biofilms developed on about 150 Petri dishes were harvested with sterile cotton buds that were then extracted twice with a mixture of dichloromethane (DCM) and methanol at 1:1 ratio at room temperature for $8 \mathrm{~h}$ with gentle agitation. The extracts were combined, filtered through Whatman filter paper No. 1, and then evaporated to dryness in vacuo. The crude extract was first dissolved in DMSO and then diluted with autoclaved FSW to concentrations ranging from 25 to $150 \mu \mathrm{g} \mathrm{ml}^{-1}$. The resulting solutions were tested for the attachment of Hydroides elegans larvae.

The crude extracts were resuspended in a 10-fold volume of Milli-Q water, and partitioned 3 times with an equal volume of DCM. The DCM fraction (the nonpolar fraction) was dried by rotary evaporation in vacuo at $35^{\circ} \mathrm{C}$ while the Milli-Q fraction (the polar fraction) was freeze-dried. Each fraction was dissolved in DMSO and then diluted with autoclaved FSW to concentrations ranging from 50 to $150 \mu \mathrm{g} \mathrm{ml}^{-1}$. The resulting solutions were tested for the larval attachment of Hydroides elegans.

After testing the larval attachment response to both the polar and non-polar extracts, $300 \mu \mathrm{g}$ of the active non-polar fraction (DCM fraction) was fractionated using reversed-phase HPLC (Lichrospher 100 RP $\mathrm{C}_{18}$ EC $5 \mu, 250 \times 4 \mathrm{~mm}$ internal diameter). Six fractions of the DCM fraction were collected from HPLC and tested for the larval attachment of Hydroides elegans again. Individual peaks from the active fraction were isolated, tested for bioactivity using larval attachment bioassays, and the structures of the pure active compounds were elucidated by ${ }^{1} \mathrm{H}$ - and ${ }^{13} \mathrm{C}$-NMR spectroscopy (Bruker DRX 500 NMR spectrometer). Fig. 1 illustrates the general procedures for separating and isolating the pure active compounds.

Hydroides elegans larval culture. Larvae of $H$. elegans were reared to the competent stage according to methods by Qian \& Pechenik (1998). The competency of the larvae was visually determined according to morphological characterizations described by Wisely 


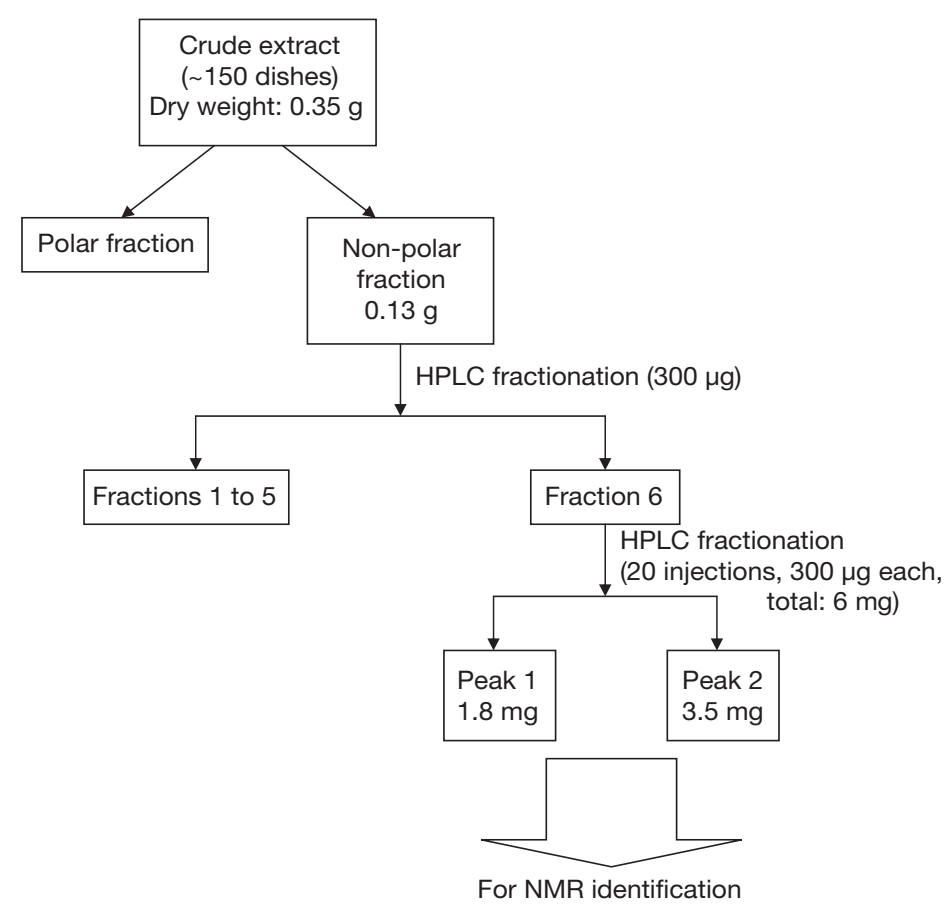

Fig. 1. Procedures of separation and isolation of pure active compounds from the crude extracts. NMR: nuclear magnetic resonance

(1958) and behaviorally with a rapid test with 3isobutyl-1-methylxanthine (IBMX) according to the method described by Qian \& Pechenik (1998). When most of the larvae in the culture were competent, the culture was gently filtered through a $110 \mu \mathrm{m}$ nylon mesh. The larvae retained on the mesh were immediately used for larval attachment bioassays.

Larval attachment bioassays. The attachment experiments were performed using a still-water bioassay setup (i.e. a single-dish bioassay) according to Qian \& Pechenik (1998). The bioassay was performed in 24well Falcon polystyrene plates. Briefly, different fractions or compounds were dissolved in DMSO and then diluted with autoclaved FSW to concentrations ranging from 25 to $150 \mu \mathrm{g} \mathrm{ml}^{-1}$. The positive control consisted of FSW plus $10^{-4} \mathrm{M}$ IBMX, and FSW plus DMSO served as the negative control. Four replicates, each receiving 20 competent larvae in $1 \mathrm{ml}$ of test solution, were used in each treatment and control. The 24 -well plates were incubated at $28^{\circ} \mathrm{C}$ under darkness. After $24 \mathrm{~h}$ of incubation, the number of successfully attached and metamorphosed individuals with calcified tube was scored. Bacterial density in each well before and after incubation was determined by DAPI staining and counting under a fluorescence microscope.

Statistical analysis. All percentage and count data were subjected to angular and log transformation, respectively, before additional statistical analysis (Zar 1999). One-way ANOVA and the Tukey multiple com- parison test were used to analyze the results of the larval attachment bioassays. A $t$-test was used to compare the bacterial density before and after the bioassays.

\section{RESULTS}

\section{Larval attachment bioassay on crude extracts from natural biofilms}

The percentage of attachment of Hydroides elegans larvae in the treatments with 100 and $150 \mu \mathrm{g} \mathrm{ml}^{-1}$ of crude extract was significantly higher than that in the negative control ( $p<0.001$, Fig. 2). However, only the treatment with $150 \mu \mathrm{g} \mathrm{ml} \mathrm{m}^{-1}$ crude extract showed a similar percentage of attachment as the positive control had. On the other hand, the percentage of attachment in the treatments with 25 and $50 \mu \mathrm{g} \mathrm{ml}^{-1}$ crude extract was significantly lower than that in the positive control ( $\mathrm{p}<0.001$ ), and both showed no significant difference when compared with the negative control $(\mathrm{p}=0.078)$.

\section{Larval attachment bioassay with DCM extract and Milli-Q extracts}

The percentage of attachment of Hydroides elegans larvae in the treatments with 100 and $150 \mu \mathrm{g} \mathrm{ml}^{-1}$ of DCM extract was significantly higher than that in the negative control $(\mathrm{p}<0.001)$, and both showed a similar percentage of attachment as the positive control had ( $p=0.27$, Fig. 3). On the other hand, the percentage of

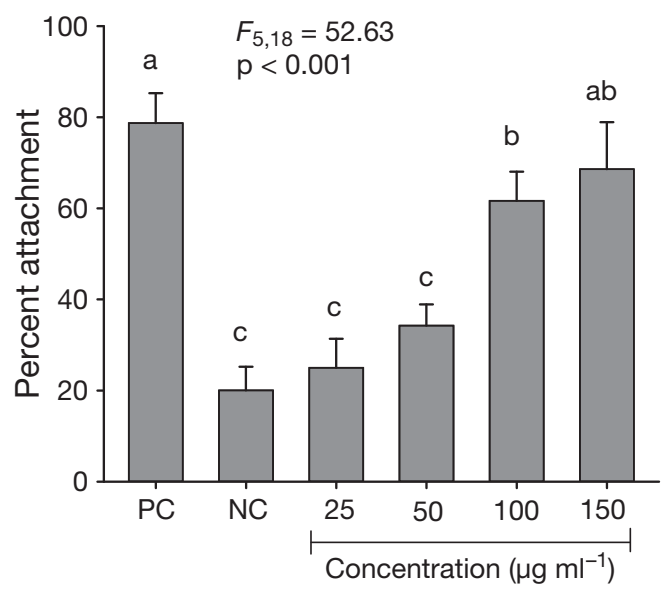

Fig. 2. Hydroides elegans. Single-dish bioassay: percentage of attachment of larvae in response to the crude extract from natural biofilm. Data are expressed as mean +1 SD of 4 replicates. Data that are significantly different at $\alpha=0.05$ in the Tukey test are indicated by different letters above the bars. PC: positive control (FSW $+10^{-4} \mathrm{M}$ IBMX); NC: negative control (FSW + DMSO) 


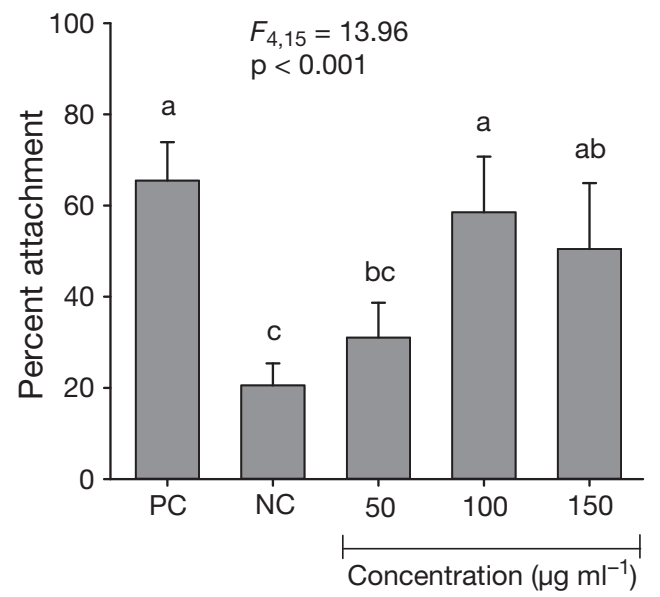

Fig. 3. Hydroides elegans. Single-dish bioassay: percentage of attachment of larvae in response to the DCM extract. Data are expressed as mean $+1 \mathrm{SD}$ of 4 replicates. Data that are significantly different at $\alpha=0.05$ in the Tukey test are indicated by different letters above the bars. PC: positive control (FSW + 10-4 M IBMX); NC: negative control (FSW + DMSO)

attachment in the treatment with $50 \mu \mathrm{g} \mathrm{ml} \mathrm{m}^{-1}$ of DCM extract was significantly lower than that in the positive control ( $p<0.001)$, and there was no significant difference when compared with the negative control $(\mathrm{p}=$ 0.596, Fig. 3).

The percentage of attachment of Hydroides elegans larvae in the treatment with $100 \mu \mathrm{g} \mathrm{ml}^{-1}$ of Milli-Q extract was significantly higher than that in the negative control, whereas it was significantly lower than that in the positive control ( $p<0.001$, Fig. 4). On the other hand, the percentage of attachment in the treatments with 50 and $150 \mu \mathrm{g} \mathrm{ml}^{-1}$ of Milli-Q extract was significantly lower

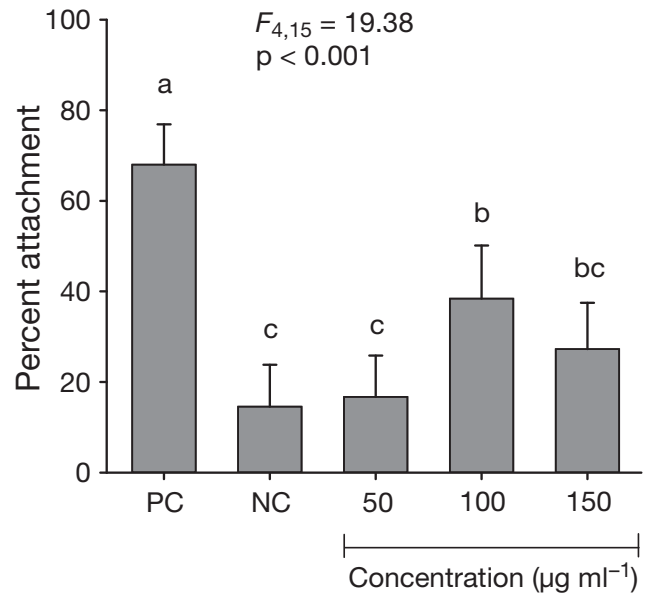

Fig. 4. Hydroides elegans. Single-dish bioassay: percentage of attachment of larvae in response to the Milli-Q water extract. Data are expressed as mean $+1 \mathrm{SD}$ of 4 replicates. Data that are significantly different at $\alpha=0.05$ in the Tukey test are indicated by different letters above the bars. PC: positive control $\left(\mathrm{FSW}+10^{-4} \mathrm{M}\right.$ IBMX); NC: negative control (FSW + DMSO)

than that in the positive control ( $p<0.001)$, and both showed no significant difference when compared with the negative control ( $\mathrm{p}=0.399$, Fig. 4$)$.

\section{Larval attachment bioassay with HPLC fractions of DCM extract}

In our HPLC tests, 6 fractions of a sample of $300 \mu \mathrm{g}$ of the DCM extract were collected separately and tested for larval attachment responses (Fig. 5). Since each fraction was redissolved in DMSO and then in auto-

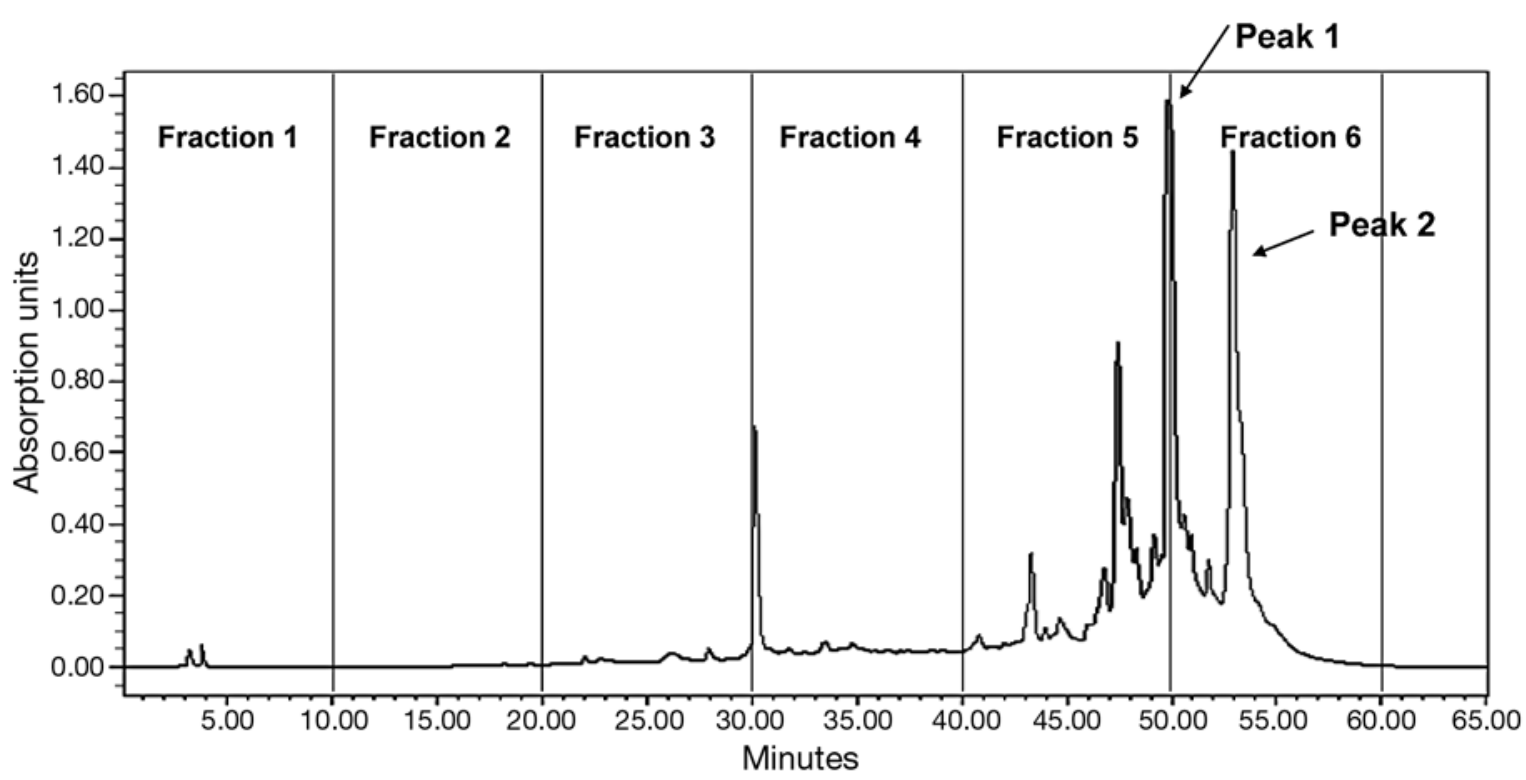

Fig. 5. HPLC chromatogram of the DCM extract. The extract was separated into 6 fractions 
claved FSW to obtain a final volume of $3 \mathrm{ml}$ for 3 replicates in the larval settlement bioassays, the concentration of compounds in each fraction being tested in the assays must not exceed $100 \mu \mathrm{g} \mathrm{ml}^{-1}$. The percentage of attachment of Hydroides elegans larvae in Fractions 5 and 6 was significantly higher than that of the negative control ( $p<0.001$, Fig. 6). However, only Fraction 6 had a percentage of attachment similar to that of the positive control $(p=0.979)$. On the other hand, the percentage of attachment in Fractions 1, 2, 3, and 4 was significantly lower than that of the positive control $(p<$ 0.001), and all showed no significant difference when compared with the negative control ( $p=0.807$, Fig. 6).

Using HPLC, compounds for 2 peaks from a sample of $300 \mu \mathrm{g}$ of Fraction 6 were collected and assayed separately (Fig. 5). Compounds of Peaks $1(90 \mu \mathrm{g})$ and 2 $(174.9 \mu \mathrm{g})$ were obtained and tested for larval settlement inductive activity at concentrations of $30 \mathrm{\mu g} \mathrm{ml}^{-1}$ and $58.3 \mu \mathrm{g} \mathrm{ml}^{-1}$, respectively. The percentage of attachment of Hydroides elegans larvae in the treatments with the compounds for Peaks 1 and 2 was significantly higher than that in the negative control $(p<0.001$, Fig. 7). However, only the compound of Peak 1 had a percentage of attachment similar to that of the positive control $(p=0.272)$. The bacterial density in the wells with the pure compounds did not differ significantly when compared with that in the negative control (data not shown, $\mathrm{p}>0.05, t$-test).

\section{Isolation and identification of inductive compounds}

By using bioassay-guided fractionation, we obtained 2 inductive compounds for Peaks $1(1.8 \mathrm{mg})$ and 2

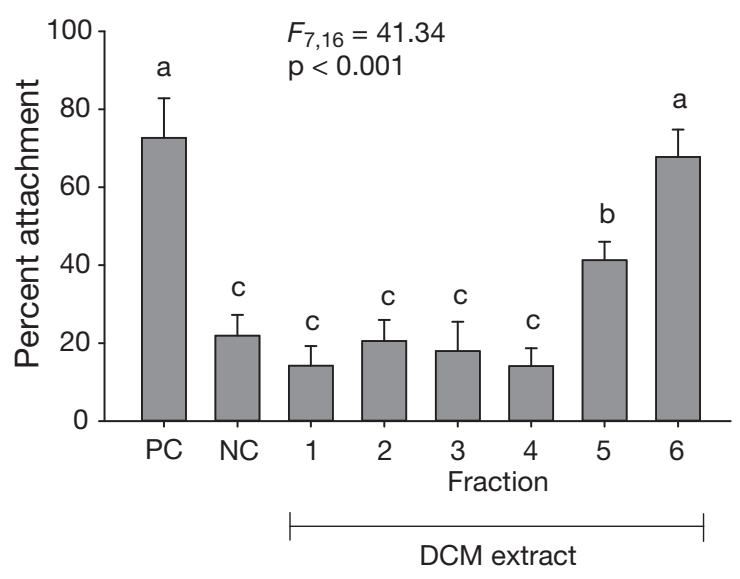

Fig. 6. Hydroides elegans. Single-dish bioassay: percentage of attachment of larvae in response to HPLC fractions (DCM extract, sample amount $300 \mu \mathrm{g}$ ). Data are expressed as mean +1 SD of 3 replicates. Data that are significantly different at $\alpha=0.05$ in the Tukey test are indicated by different letters above the bars. PC: positive control (FSW + $10^{-4} \mathrm{M}$ IBMX); NC: negative control (FSW + DMSO)

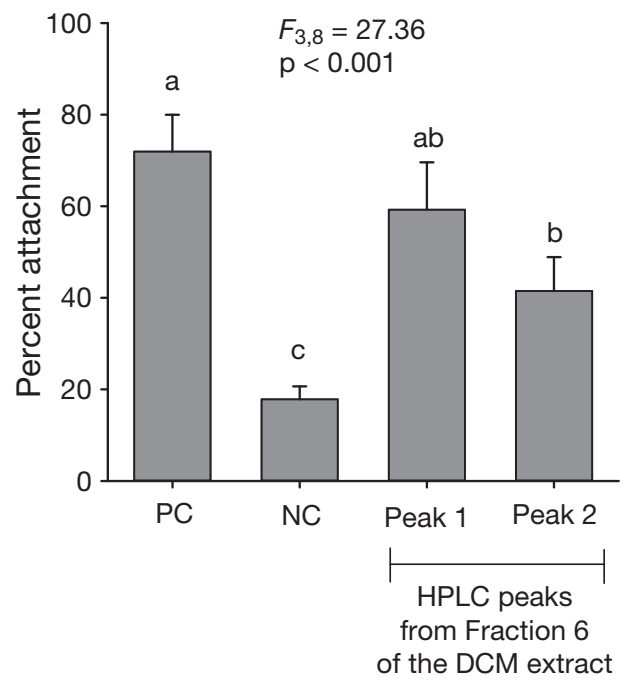

Fig. 7. Hydroides elegans. Single-dish bioassay: percentage of attachment of larvae in response to pure compounds (Peaks 1 and 2) from Fraction 6 of the DCM extract (HPLC, sample amount $300 \mu \mathrm{g}$ ). Data are expressed as mean +1 SD of 3 replicates. Data that are significantly different at $\alpha=0.05$ in the Tukey test are indicated by different letters above the bars. PC: positive control (FSW $+10^{-4} \mathrm{M}$ IBMX); NC: negative control (FSW + DMSO)

(3.5 mg), from $6 \mathrm{mg}$ of active Fraction 6 of the DCM extract (20 injections of $300 \mu \mathrm{g}$ each of the non-polar extract into HPLC, Fig. 5). The chemical structure of the 2 pure compounds was determined by analyzing the ${ }^{1} \mathrm{H}-\mathrm{NMR},{ }^{13} \mathrm{C}-\mathrm{NMR}$, and mass spectrometry spectra and compared with references. Their chemical identities were identified as 6,9-heptadecadiene (Peak 1) and 12-octadecenoic acid (Peak 2) (Figs. 8 \& 9). However, as these 2 compounds are not commercially available, pure compounds from commercial sources could not be used for spectral comparison and bioassay testing.

\section{DISCUSSION}

Chemical cues for larval attachment can be derived from conspecific adults (Burke 1986), host organisms (Williamson et al. 2000), prey (Hadfield \& Scheuer 1985), or biofilms (Wieczorek \& Todd 1998). However, only limited studies have attempted to characterize these attachment cues (reviewed by Hadfield \& Paul 2001). One of the reasons for the lack of such studies is that larvae may respond to specific cues that are present only at very low concentrations, making it difficult to detect them and to obtain an adequate amount for purification and identification (Hadfield \& Paul 2001). Even though the chemical identities of some of these cues are known, their ecological relevance is not yet clear. For example, lumichrome isolated from the tuni- 


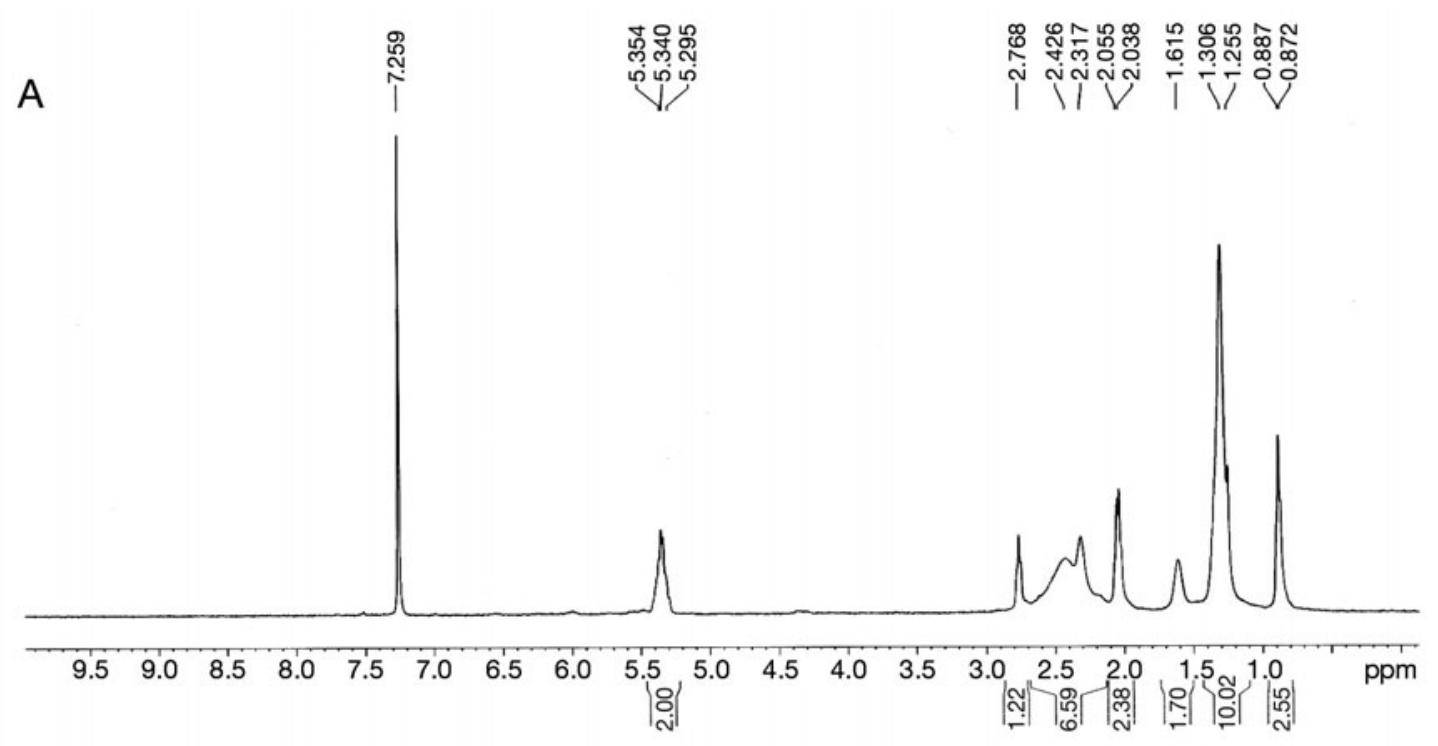

B

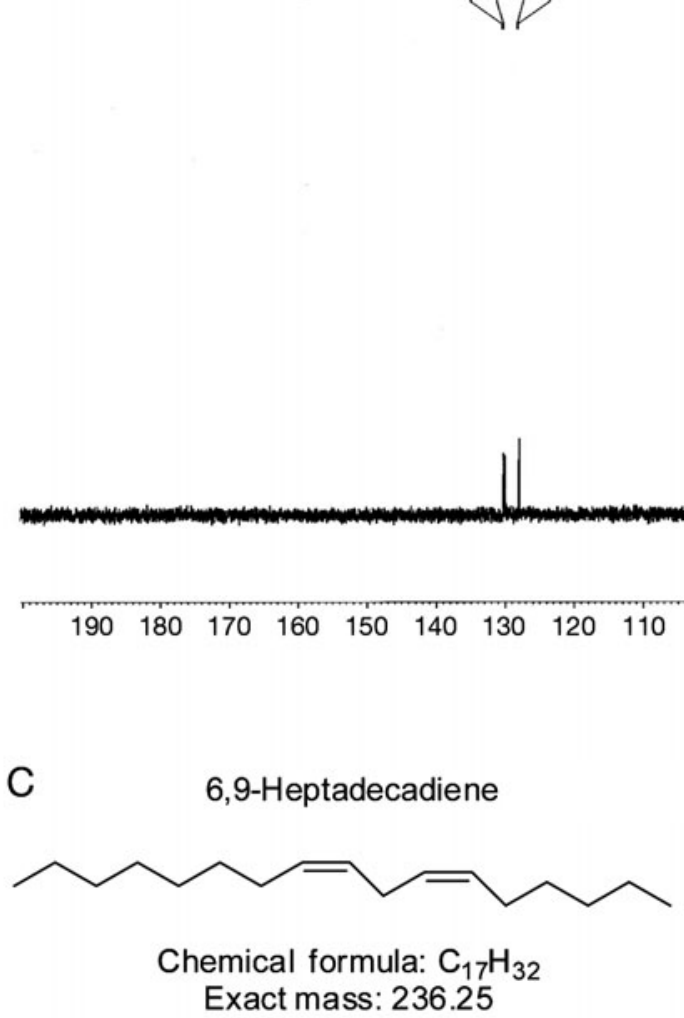

cate tissue of conspecific adults induced attachment of ascidian larvae in the laboratory, but larvae do not encounter this inductive compound in the natural environment (Tsukamoto et al. 1999).

Apart from cues derived from conspecific adults, biofilms (which larvae, like all marine organisms, easily
Fig. 8. (A) ${ }^{1} \mathrm{H}-\mathrm{NMR}$ and (B) ${ }^{13} \mathrm{C}-\mathrm{NMR}$ spectra of Peak 1 from Fraction 6 of the DCM extract. (C) The active compound was identified as 6,9-heptadecadiene. Vertical numbers: chemical shift (frequency of absorption) of peak

encounter in the natural environment) have long been recognized as a source of attachment cues for many benthic marine invertebrates (reviewed by Hadfield \& Paul 2001). We demonstrated that larvae of the barnacle Balanus amphitrite could distinguish biofilms originating from contrasting environments and attached preferen- 

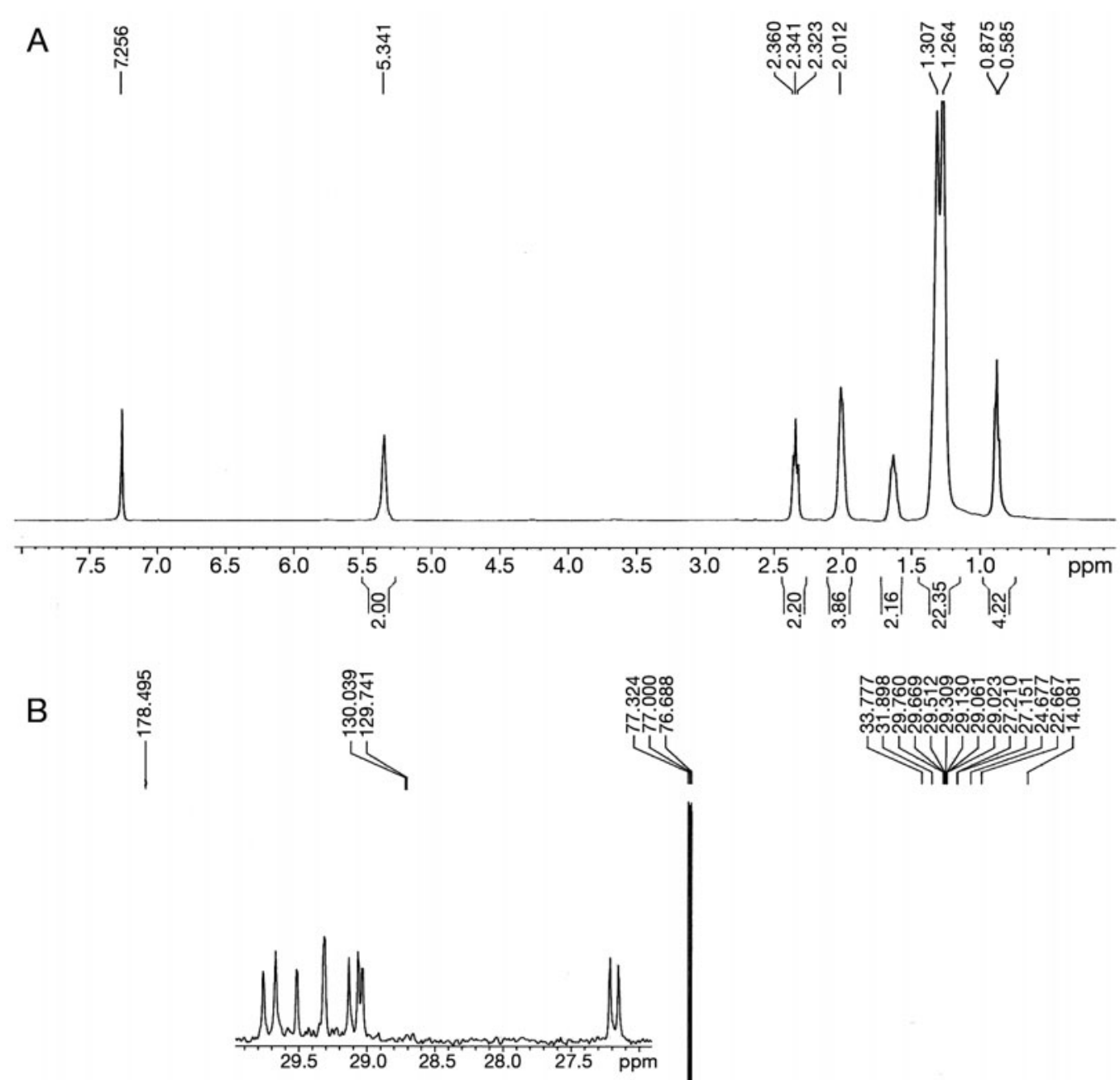

C

12-Octadecenoic acid

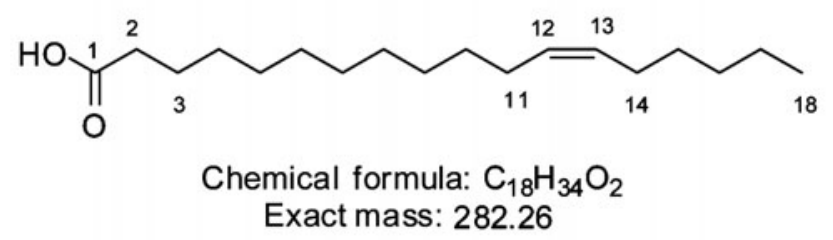

Fig. 9. (A) ${ }^{1} \mathrm{H}-\mathrm{NMR}$ and (B) ${ }^{13} \mathrm{C}-\mathrm{NMR}$ spectra of Peak 2 from Fraction 6 of the DCM extract. (C) The active compound was identified as 12-octadecenoic acid. Vertical numbers: chemical shift (frequency of absorption) of peak

tially to biofilms from a habitat that supports higher recruitment and juvenile survival (Hung et al. 2007), leading to the argument that differential attachment is due to different chemical cues derived from natural biofilms. However, up to now, no chemical cues from natural biofilms have been fully characterized. The present study, for the first time, characterized the chemical compounds from natural biofilms which could induce larval attachment of Hydroides elegans. By using larval settlement bioassays, we found that the non-polar frac- 
tion (DCM extract) of crude extracts of biofilms induced a higher percentage of larval attachment than the polar fraction, an observation that is in good agreement with previous studies showing that larval attachment cues are mainly surface-bound and non-polar (Pawlik 1986, 1992). Further bioassay-guided fractionation and purification by HPLC resulted in the isolation of 2 inductive compounds. Structural characterization by NMR revealed that the active compounds were an unsaturated hydrocarbon with 17 carbons (6,9-heptadecadiene) and a fatty acid with 18 carbons (12-octadecenoic acid).

This is the first study to identify, isolate, and characterize a hydrocarbon and a fatty acid from natural biofilms as inductive chemical compounds for the attachment of Hydroides elegans larvae. Several previous studies have shown that fatty acids are involved in inducing larval attachment responses. For example, a mixture of free fatty acids (FFAs) isolated from the coralline red alga Corallina pilulifera, dominated by eicosapentaenoic acid, palmitic acid, arachidonic acid, and palmitoleic acid, induced attachment of the larvae of 2 sea urchins, Pseudocentrotus depressus and Anthocidaris crassispina (Kitamura et al. 1993). Another example is polychaete larvae. A natural mixture of FFAs dominated by cis-5, 8,11,14,17-eicosapentaenoic acid, palmitic acid, and palmitoleic acid induced attachment of the larvae of Phragmatopoma californica (Pawlik 1986). Pawlik \& Faulkner $(1986,1988)$ showed that the response of $P$. californica larvae to FFAs is dependent on the concentration and the presence of at least 1 double bond in the molecule.

While there are more studies on the inductive effect of fatty acids on larval attachment and metamorphosis (Pawlik 1986, Pawlik \& Faulkner 1986, 1988, Kitamura et al. 1993), the effects of hydrocarbons on larval attachment are relatively understudied. So far, Banks \& Brown (2002) have been the only investigators to report that the water-soluble fraction of crude oil facilitates recruitment of oyster and barnacle larvae but inhibits recruitment of bryozoan larvae. In the present study, the inductive hydrocarbon was isolated from the non-polar fraction of the crude extract of biofilms. Direct contact may be required for non-polar compounds to exert an inductive activity on larvae for attachment and metamorphosis. Others reported that direct contact with microbial films formed on the substrata surface could promote the settlement of actinula larvae of the marine colonial hydroid Tubularia mesembryanthemum (Yamashita et al. 2003).

Work conducted in our laboratory reported inductive activity of dissolved free amino acids (DFAAs) purified from the body homogenate of adult Hydroides elegans to induce larval attachment of this species (Harder \& Qian 1999). We further studied whether DFAAs promote larval attachment of $H$. elegans indirectly by facilitating biofilm development, but we did not fully rule out the possibility of a direct effect of DFAAs on larval attachment (Beckman et al. 1999). Two follow-up studies (Jin \& Qian 2004, 2005) demonstrated clearly that some of those DFAAs induced larval attachment of $H$. elegans indirectly by changing bacterial community structures of biofilm, while some induced larval attachment of $H$. elegans directly without changing biofilm community structure, suggesting the inductive activity of DFAAs on larval attachment is amino-acid-species dependent. In the bioassay system used in the present study, biofilm development is unavoidable. Although we did not observe changes in bacterial density upon addition of the purified compounds into testing wells, we cannot rule out an indirect inductive effect of the compounds on larval attachment by alteration of bacterial species composition in biofilm. How the compounds isolated in the present study may affect the bacterial species composition in subsequent biofilm development and eventually lead to an inductive effect on larval attachment remains to be investigated.

In the present study, the concentration of the active fraction or compound in the natural environment could not be determined. However, when performing bioassays, the concentrations of the extract or fraction were adjusted to be lower than those in the natural setting. For instance, 0.35 and $0.13 \mathrm{~g}$ of crude extract and nonpolar fraction were obtained from 150 dishes, respectively, meaning that $2333 \mu \mathrm{g}$ of crude extract and $867 \mu \mathrm{g}$ of non-polar fraction were obtained from each dish. However, the amounts of crude extract or nonpolar fraction used in the bioassays ranged from 50 to $100 \mu \mathrm{g}$, which were far lower than those in the natural setting. For the bioassays with fractions from HPLC or pure compounds, the resulting isolates were concentrated and redissolved in the same volume of FSW as in the preceding sample to adjust the concentration of active fraction or compound to be equivalent to that in the original sample. On the other hand, recent studies have shown that larval attachment might be regulated synergistically by multiple natural cues. For example, the bromotyrosine derivative and carotenoids have a synergistic effect on attachment of the larvae of the coral Pseudosiderastrea tayamai (Kitamura et al. 2007). Although we demonstrated in the present study that 2 chemical compounds induced a high percentage of larval attachment (Fig. 6), we could not rule out the possibility that other compounds might be involved in inducing larval attachment, as different chemical compounds in natural biofilms may interact synergistically or antagonistically.

Overall, the evidence presented here suggests that a fatty acid and a hydrocarbon isolated from natural biofilms induced the attachment of Hydroides elegans larvae. However, the quantitative distribution of these 
inductive cues in natural biofilms, the in situ concentration of these cues in the natural environment, the mechanisms by which the cues induced larval attachment, the synergistic or antagonistic effects between different chemical compounds, and the potential producers of these compounds remain to be investigated.

Acknowledgements. This study was supported by RGC grants (662207 and HKUST6402/05M) to P.Y.Q. and also by the UGC Area of Excellence program (AoE/P-04/2004).

\section{LITERATURE CITED}

Banks PD, Brown KM (2002) Hydrocarbon effects on fouling assemblages: the importance of taxonomic differences, seasonal, and tidal variation. Mar Environ Res 35:157-166

Barnes H (1956) Surface roughness and the settlement of Balanus balanoides (L.). Arch Soc Zool Bot Fenn Vanamo 10:164-168

Beckmann M, Harder T, Qian PY (1999) Induction of larval attachment and metamorphosis in the serpulid polychaete Hydroides elegans by dissolved free amino acids: mode of action in laboratory bioassays. Mar Ecol Prog Ser 190: $167-178$

Burke RD (1986) Pheromones and the gregarious settlement of marine invertebrate larvae. Bull Mar Sci 39:323-331

Dahlström M, Jonsson H, Jonsson PR, Elwing H (2004) Surface wettability as a determinant in the settlement of the barnacle Balanus improvisus (Darwin). J Exp Mar Biol Ecol 305:223-232

> Decho AW (2000) Microbial biofilms in intertidal systems: an overview. Cont Shelf Res 20:1257-1273

Hadfield MG, Paul VJ (2001) Natural chemical cues for the settlement and metamorphosis of marine invertebrate larvae. In: McClintock JG, Baker BJ (eds) Marine chemical ecology. CRC Press, Boca Raton, FL, p 431-461

Hadfield MG, Scheuer D (1985) Evidence for a soluble metamorphic inducer in Phestilla: ecological, chemical and biological data. Bull Mar Sci 37:556-566

- Harder T, Qian PY (1999) Induction of larval attachment and metamorphosis in the serpulid polychaete Hydroides elegans by dissolved free amino acids: isolation and identification. Mar Ecol Prog Ser 179:259-271

> Hung OS, Thiyagarajan V, Zhang R, Wu RSS, Qian PY (2007) Attachment of Balanus amphitrite larvae to biofilms originating from contrasting environments. Mar Ecol Prog Ser 333:229-242

> Jeffery CJ (2002) New settlers and recruits do not enhance settlement of a gregarious intertidal barnacle in New South Wales. J Exp Mar Biol Ecol 275:131-146

$>$ Jin T, Qian PY (2004) Effect of amino acids on larval metamorphosis of the polychaete Hydroides elegans. Mar Ecol Prog Ser 267:209-218

> Jin T, Qian PY (2005) Amino acid exposure modulates the bioactivity of biofilms for larval settlement of Hydroides elegans by altering bacterial community components. Mar Ecol Prog Ser 297:169-179

Kirchman D, Graham S, Reish D, Mitchell R (1981) Bacteria induce settlement and metamorphosis of Janua (Dexiospira) brasiliensis Grube (Polychaeta: Spirorbidae). J Exp Mar Biol Ecol 56:153-163

Kitamura H, Kitahara S, Koh HB (1993) The induction of larval settlement and metamorphosis of two sea urchins, Pseudocentrotus depressus and Anthocidaris crassispina, by free fatty acids extracted from the coralline red alga Corallina pilulifera. Mar Biol 115:387-392

Kitamura M, Koyama T, Nakano Y, Uemura D (2007) Characterization of a natural inducer of coral larval metamorphosis. J Exp Mar Biol Ecol 340:96-102

Lau SCK, Thiyagarajan V, Cheung SCK, Qian PY (2005) Roles of bacterial community composition in biofilms as a mediator for larval settlement of three marine invertebrates. Aquat Microb Ecol 38:41-51

Matsumura K, Nagano M, Fusetani N (1998) Purification of a larval settlement-inducing protein complex (SIPC) of the barnacle, Balanus amphitrite. J Exp Zool 281:12-20

> Pawlik JR (1986) Chemical induction of larval settlement and metamorphosis in the reef-building tube worm Phragmatopoma californica (Sabellariidae: Polychaeta). Mar Biol 91:59-68

Pawlik JR (1992) Chemical ecology of the settlement of benthic marine invertebrates. Oceanogr Mar Biol Annu Rev 30:273-335

> Pawlik JR, Faulkner DJ (1986) Specific free fatty acids induce larval settlement and metamorphosis of the reef-building tube worm Phragmatopoma californica (Fewkes). J Exp Mar Biol Ecol 102:301-310

Pawlik JR, Faulkner DJ (1988) The gregarious settlement of sabellariid polychaetes: new perspectives on chemical cues. In: Thompson M, Sarjoini R, Nagabhushanam R (eds) Marine biodeterioration: advanced techniques applicable to the Indian Ocean. Oxford and IBH Publishing, New Delhi, p 475-487

> Qian PY, Pechenik JA (1998) Effects of larval starvation and delayed metamorphosis on juvenile survival and growth of the tube-dwelling polychaete Hydroides elegans (Haswell). J Exp Mar Biol Ecol 227:169-185

Qian PY, Thiyagarajan V, Lau SCK, Cheung SCK (2003) Relationship between bacterial community profile in biofilm and attachment of the acorn barnacle Balanus amphitrite. Aquat Microb Ecol 33:225-237

Saucedo PE, Bervera-Leon H, Monteforte M (2005) Factors influencing recruitment of hatchery reared pearl oyster (Pinctada mazatlanica; Hanley 1856) spat. J Shellfish Res 24:215-219

Swanson RL, Williamson JE, de Nys R, Kumar N, Bucknall MP, Steinberg PD (2004) Induction of settlement of larvae of the sea urchin Holopneustes purpurascens by histamine from a host alga. Biol Bull (Woods Hole) 206:161-172

Szewzyk U, Holmström C, Wrangstadh M, Samuelsson MO, Maki JS, Kjelleberg S (1991) Relevance of the exopolysaccharide of marine Pseudomonas sp. S9 for the attachment of Ciona intestinalis larvae. Mar Ecol Prog Ser 75:259-265

Thorson G (1950) Reproductive and larval ecology of marine bottom invertebrates. Biol Rev Camb Philos Soc 25:1-45

Tsukamoto S, Kato H, Hirota H, Fusetani N (1995) Pipecolate derivatives, anthosamines $\mathrm{A}$ and $\mathrm{B}$, inducers of larval metamorphosis in ascidians, from a marine sponge Anthosigmella aff. raromicrosclera. Tetrahedron 51:6687-6694

> Tsukamoto S, Kato H, Hirota H, Fusetani N (1999) Lumichrome: a larval metamorphosis-inducing substance in the ascidian Halocynthia roretzi. Eur J Biochem 264:785-789

Webster NS, Smith LD, Heyward AJ, Watts JEM, Webb RI, Blackall LL, Negri AP (2004) Metamorphosis of a scleractinian coral in response to microbial biofilms. Appl Environ Microbiol 70:1213-1221

Wieczorek SK, Todd CD (1998) Inhibition and facilitation of settlement of epifaunal marine invertebrate larvae by microbial biofilm cues. Biofouling 12:81-118

Wieczorek SK, Murray AWA, Todd CD (1996) Seasonal variation in the effects of hard substratum biofilming on settle- 
ment of marine invertebrate larvae. Biofouling 10:309-330 Williamson JE, de Nys R, Kumar N, Carson DG, Steinberg PD (2000) Induction of metamorphosis in the sea urchin Holopneustes purpurascens by a metabolite complex from the algal host Delisea pulchra. Biol Bull (Woods Hole) 198: 332-345

> Wisely B (1958) The development and settling of a serpulid worm, Hydroides norvegica Gunnerus (Polychaeta). Aust J Mar Freshw Res 9:351-361

Yamashita K, Kawaii S, Mitsuyo Nakai M, Fusetani N (2003)

Editorial responsibility: Michael Kühl,

Helsingør, Denmark
Larval behavioral, morphological changes, and nematocyte dynamics during settlement of actinulae of Tubularia mesembryanthemum, Allman 1871 (Hydrozoa: Tubulariidae). Biol Bull (Woods Hole) 204:256-269

- Yvin JC, Chevolet L, Chevolet-Maguer AM, Cochard JC (1985) First isolation of jacarone from an alga Delesseria sanguinea: a metamprphosis inducer of Pecten larvae. J Nat Prod 48:814-816

Zar JH (1999) Biostatistical analysis, 4th edn. Prentice Hall, Englewood Cliffs, NJ

Submitted: March 14, 2008; Accepted: November 5, 2008 Proofs received from author(s): January 12, 2009 